\title{
Streamflow permanence curve of the river Timbó, Santa Catarina, Brazil
}

\author{
Álvaro José Backª, Gustavo José Deibler Zambranob, Cláudia Weber Corseuilc \\ a Empresa de Pesquisa Agropecuária e Extensão Rural de Santa Catarina, Estação Experimental de Urussanga, Urussanga, 88840- \\ 000, Santa Catarina, Brazil. *ajb@epagri.sc.gov.br \\ b Departamento de Engenharia de Agrimensura, Universidade do Extremo Sul Catarinense, Criciúma, 88806-000, Santa Catarina, \\ Brazil. \\ c Programa de Pós-Graduação em Energia e Sustentabilidade, Centro de Ciências, Tecnologia e Saúde, Departamento de Energia e \\ Sustentabilidade, Universidade Federal de Santa Catarina, Araranguá, 88906-072, Santa Catarina, Brazil.
}

Received: April 8, 2019 / Accepted: May 4, 2019 / Published online: May 27, 2019

\begin{abstract}
The permanence curve is used as a source of information on water availability. It is adopted as a reference in the processes of management of water resources. In the present study, the streamflow permanence curve of the Timbó River, located in the Northern Plateau of Santa Catarina, was evaluated and modeled. Daily streamflow data of the fluvial station Santa Cruz do Timbó (Code 65295000) were used for the period from 1975 to 2005. Thus, permanence curves can be established for monthly streamflows and daily streamflows. The values were rendered dimensionless by the average long-term streamflow, and adjusted to the Rational model. The daily streamflow permanence curves were also determined for each month, and the models for these non-dimensioned streamflows were adjusted by the average monthly streamflows. The results show that the use of the monthly permanence curve overestimates the streamflow values by frequencies higher than $20 \%$. The adjusted models allow estimating the streamflow with a small estimation standard error. The coefficient of determination is higher than 0.99 .
\end{abstract}

Keywords: Extreme events, hydrology, granting, minimum streamflows.

\section{Curve of permanence of flows of the river Timbó, State of Santa Catarina, Brazil}

\begin{abstract}
Resumo
A curva de permanência é utilizada como informação de disponibilidade hídrica, sendo adotadas como referência nos processos de gestão de recursos hídricos. No presente estudo foi avaliada e modelada a curva de permanência de vazões do rio Timbó, localizado no Planalto Norte de Santa Catarina. Foram utilizados os dados diários de vazão da estação fluviométrica Santa Cruz do Timbó (Código 65295000) referente ao período de 1975 a 2005. Desta forma, pode-se estabelecer as curvas de permanência para vazões mensais e vazões diárias. Os valores foram adimensionalizados pela vazão média de longo termo e ajustados ao modelo Racional. Também foram determinadas as curvas de permanência de vazões diárias para cada mês, e ajustados os modelos para estas vazões adimensionalizadas pelas vazões médias mensais. Os resultados obtidos mostram que a utilização da curva de permanência mensal superestima os valores de vazão com frequências superiores a $20 \%$. Os modelos ajustados permitem estimar a vazão com pequeno erro padrão de estimativa, sendo os valores do coeficiente de determinação superior a 0,99 .
\end{abstract}

Palavras-chave: Eventos extremos, hidrologia, outorga, vazões mínimas.

\section{Introduction}

The natural water availability of a river basin, characterized by minimum streamflows, is a fundamental information for the implementation of water resource management instruments (Mello, Viola \& Beskow, 2010; Pereira \& Caldeira, 2018). The reference streamflow is used as the basis for the process of water resource management (Fioreze \& Oliveira, 2010).

When there are historical series of streamflows of a watercourse, water availability can be established based on streamflow rate studies (Pandey, \& Nguyen, 1999; Arias \&
Serna, 2017). Such studies can be conducted based on probability functions of streamflow occurrence, such as medium and minimum streamflows or streamflow permanence curve (Oliveira \& Fioreze, 2011, Gasques, Neves, Santos, Mauad \& Okawa, 2018).

The permanence curve has been used for the evaluation and characterization of minimum streamflows (Tucci, 2002; Cruz $\&$ Tucci, 2008). The permanence curve represents the relation between the magnitude and frequency of daily, weekly or monthly streamflows of a given river basin, indicating the percentage of time with which a given streamflow is equalized 
or exceeded in a defined historical period.

The minimum streamflows are also used for navigation projects, irrigation, hydroelectric power generation, and sectoral supply projects (Eletrobras, 2000; Cruz \& Tucci, 2008, Gasques et al., 2018). The permanence curve can be used in association with water quantity and quality, for applications in environmental studies, and for studying water bodies (Cunha, Calijuri, \& Mendindo, 2012; Ferreira, Fernandes \& Kaviski, 2016; Calmon, Souza, Reis \&. Mendonça, 2016).

Water management agencies of some Brazilian states use minimum streamflow rates extracted from permanence curves as a criterion for granting water resources use (Vasco, Netto \& Pruski, 2017). Normally, minimum streamflows associated with permanence streamflows of $95 \%\left(Q_{95}\right)$ and $90 \%\left(Q_{90}\right)$ are adopted. Percentage values are assigned to them, that is, granting only part of the minimum reference streamflow values (Silva \& Ramos, 2001; Vestena, Oliveira, Cunha, \& Thomaz, 2012).

Due to the lack of measured information at the site of interest, it is necessary to use tools that help to obtain information about the hydrological behavior of the basin (Pandey \& Nguyen, 1999; Gasques et al., 2018). Thus, regionalization has been used to transfer information from one location to another within an area with a similar hydrological behavior (Tucci, 2002; Eslamian \& Biabanak, 2008).

The regionalization of the permanence curve and the mathematical modeling of this hydrological variable allow the implementation of computational tools applied to the management of water resources.

Thus, the present study aims to model and evaluate the seasonal variation of minimum streamflow permanence curve of the Timbó River, located in the Northern Plateau of Santa Catarina.

\section{Material and Methods}

The study area is the watershed of the Timbó River (2,724 $\mathrm{km}^{2}$ ) located in the Planalto Norte of Santa Catarina, which is part of the hydrographic region RH5 - Planalto de Canoinhas (Santa Catarina, 2007). This basin encompasses the areas of 11 municipalities. The municipalities of Bela Vista do Toldo, Irineópolis, Matos Costa, Porto União and Timbó Grande are fully inserted inside the basin. The municipalities of Calmon, Caçador, Canoinhas, Lebon Régis, Major Vieira and Santa Cecilia are partially inserted inside the basin.

The Timbó river basin presents a relatively good water quality when compared to the other basins of the state (Santa Catarina, 2007). Nevertheless, there are pockets of pollution of water resources in this basin related to domestic sewage, industrial effluents, pollution by pesticide residues (especially by crops), reforestation, and swine farming. The basin of the Timbó River is one of the Santa Catarina basins with less problems due to contamination by domestic effluents, since it has an urban population of a little more than 6,000 people inside its drainage area (Santa Catarina, 2018).

The region has a high energy potential. Currently, several SHPs (small hydro power plants) operate in the hydrographic basin, and others are planned, according to data available

\section{from the National Electric Energy Agency (ANEEL).}

In the present study, the daily streamflow data of the Santa Cruz do Timbó river station (code 65295000) were used. The basin has drainage area of 2,610 $\mathrm{km}^{2}$ (Figure 1), and belongs to the Hydrological Network of the National Water Agency (ANA).

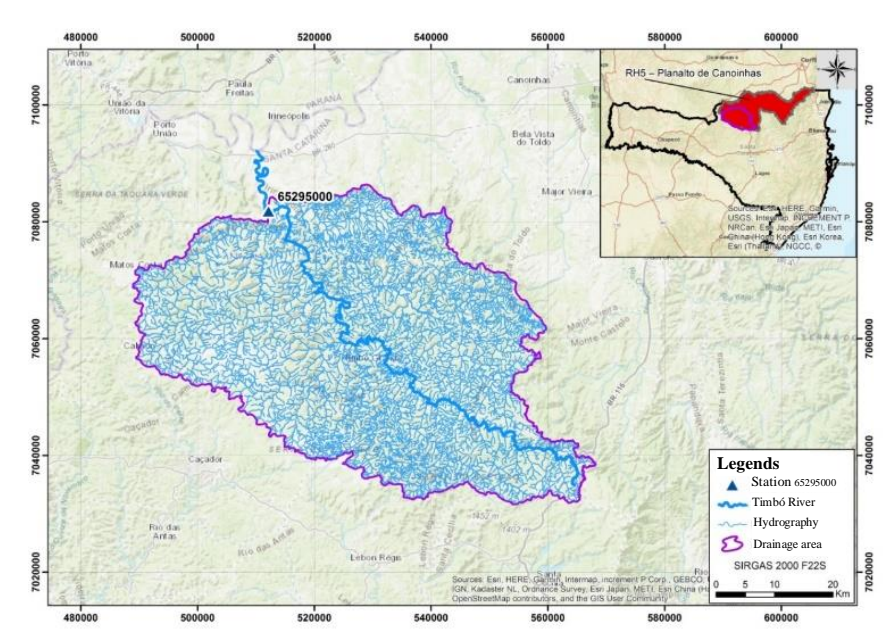

Figure 1. Location and drainage area of Santa Cruz do Timbó River Station (ANA 65295000).

The methodology for determination of the permanence curve was described by Tucci (2013) and adapted in this work with the use of individual values of minimum streamflows instead of being grouped in classes. Thus, the permanence curve was established, ordering the data in an ascending order and calculating the accumulated frequencies of values equal to or greater than the streamflow value $(\mathrm{Qj})$. The probability $(\mathrm{Pj})$ of streamflow values greater than or equal to $\mathrm{Qj}$ was calculated as:

$$
P_{j}=\frac{F a c}{N} 100
$$

Where $\mathrm{Pj}$ is the probability of streamflow values to be matched or exceeded (\%); Fac is the cumulative frequency of the streamflow values; and $\mathrm{N}$ is the number of data analyzed. For the present study, 370 monthly data and 11,390 daily streamflow data were used.

The permanence curve is given by the graph obtained by the values of $\mathrm{Pj}$ in the abscissa and $\mathrm{Qj}$ in the ordinate. In the present study, the curve of permanence of monthly streamflows and daily streamflows was determined. The streamflow values of the monthly permanence curve were dimensioned by the mean long-term streamflow rate (QMLT). Using dimensionless values, the Rational model was adjusted, according to the following expression:

$$
\frac{Q_{P}}{Q_{M L T}}=\frac{a+b P}{1+c+d P^{2}}
$$

Where: Qp is the monthly streamflow with permanence $\mathrm{P}$ $\left(\mathrm{m}^{3} \cdot \mathrm{s}^{-1}\right)$; QMLT is long term average streamflow $\left(\mathrm{m}^{3} \cdot \mathrm{s}^{-1}\right)$; $\mathrm{P}$ is the percentage of permanence $(\%) ; \mathrm{a}, \mathrm{b}, \mathrm{c}, \mathrm{d}$ are the coefficients to be adjusted.

The daily streamflow permanence curves were also determined considering only the data of each month. These data were dimensioned by the average monthly streamflow, 
and later the Rational model was adjusted according to

$$
\frac{Q_{P}}{Q_{M m}}=\frac{a+b P}{1+c+d P^{2}}
$$

Where: QP is the daily streamflow with permanence $\mathrm{P}$ $\left(\mathrm{m}^{3} \cdot \mathrm{s}^{-1}\right)$; QMm is monthly average streamflow $\left(\mathrm{m}^{3} . \mathrm{s}^{-1}\right)$; $\mathrm{P}$ is the percentage of permanence $(\%) ; \mathrm{a}, \mathrm{b}, \mathrm{c}, \mathrm{d}$ are the coefficients to be adjusted.

\section{Results and Discussion}

The average monthly streamflow rate varies from 9,559 $\mathrm{m}^{3} \cdot \mathrm{s}^{-1}$ (in April) to $122,596 \mathrm{~m}^{3} \cdot \mathrm{s}^{-1}$ (in October), with a longterm average streamflow of $79,262 \mathrm{~m}^{3} \cdot \mathrm{s}^{-1}$ (Figure 2). In October alone, the monthly streamflow with $50 \%$ of frequency exceeds the average long-term streamflow. The monthly streamflows have an asymmetric distribution with the presence of extreme events, which is directly related to the rainfall regime of the region. According to Santa Catarina (2007), the tributaries of the Iguaçu River in the territory of Santa Catarina, because they are located in an area of transition between tropical and subtropical regimes, have characteristics of a complex regime, although their behaviors are also controlled by the rainfall regime.

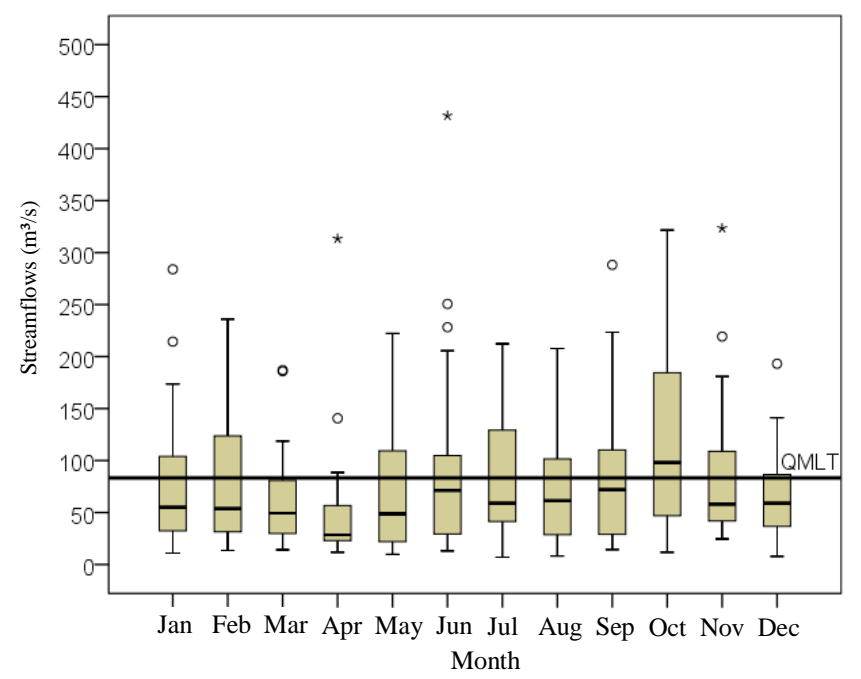

Figure 2. Monthly streamflows and long-term average streamflow (QMLT) of the Timbó River basin, Santa Catarina.

Figure 3 shows the permanence curves of monthly streamflows and of daily streamflows. For a permanence above $20 \%$, the daily streamflows are lower than the monthly streamflows. For a permanence above $50 \%$, this difference is greater than $20 \%$. This finding is important for hydroelectric projects that operate by run-of-river or with small volume reservoirs. In these cases, if a project design or feasibility study is carried out based on the monthly streamflow permanence curve, one can overestimate the capacity of the project and also interfere with the environmental preservation streamflow, as recommended by environmental agencies at $\mathrm{Q}_{7 ; 10}$. For basins of lower catchment area, it is reasonable to assume that these differences are even greater.

The Administrative Order of the Sustainable Development Secretariat (SDS) no. 36, dated July 29, 2008, together with SDS Ordinance no. 51, dated October 2, 2008, address the technical criteria for granting the right to use water resources for the extraction of surface water in the rivers of the state of Santa Catarina. Such legislation is the legal instrument that determines that, for the analysis of water availability for abstraction or derivation of watercourses in the state of Santa Catarina, $Q_{98}$ (permanence streamflow of $98 \%$ of the time) will be adopted as a reference streamflow. Nevertheless, it also defines that the granting streamflow will be equivalent to $50 \%$ of the reference streamflow. It also establishes that the maximum individual limit for consumptive uses to be granted in the portion of the river basin bounded by each river section shall be set at $20 \%$ of the discharge, and may exceed up to the limit of $80 \%$ of the discharge, when used for human consumption, provided that its use is considered rational. Table 1 also shows that the $\mathrm{Q}_{98}$ obtained with the daily data series is $8,554 \mathrm{~m}^{3} . \mathrm{s}^{-1}$, which is $26.8 \%$ lower than the value obtained with the monthly series $\left(11,679 \mathrm{~m}^{3} \cdot \mathrm{s}^{-1}\right)$, that is, one can think of instantaneously removing $3,125 \mathrm{~m}^{3} . \mathrm{s}^{-1}$ of water availability.

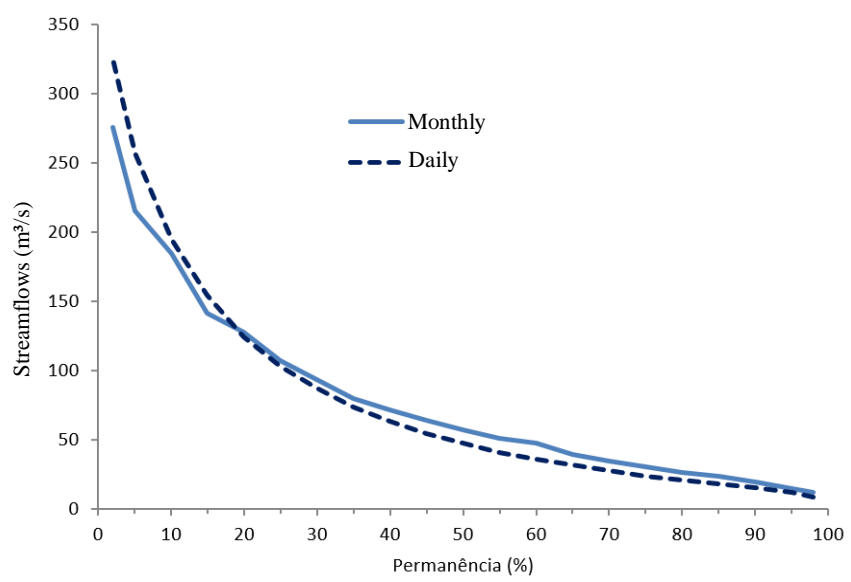

Figure 3. Monthly streamflow permanence curve and daily streamflows of the Timbó River.

For the average monthly streamflows, the adjusted model presented an estimate standard error of 0.0491 and a $\mathrm{R}^{2}$ of 0.9987 , and is given by:

$$
\frac{Q P}{Q M L T}=\frac{3,88556+0,03574 P}{1+0,06126 P-0,00045 P^{2}}
$$

For daily streamflows, the adjusted model presented an estimate standard error of 0.0163 and a $\mathrm{R}^{2}$ of 0.9999 , and is given by:

$$
\frac{Q P}{Q M L T}=\frac{4,8329-0,03950 P}{1+0,08272 P-0,00016 P^{2}}
$$

Some works were conducted to adjust the permanence curve to the mathematical models. In general, there is not a good fit for the entire range of permanence values. Pessoa, Blanco and Martins (2011) calibrated five mathematical models to represent the permanence curve of seven river stations. The authors obtained a better fit for the cubic model, with $\mathrm{R}^{2}$ varying from 0.91 to 0.98 . Arias and Serna (2017) proposed an alternative method to represent the permanence curves in function of the average streamflow for six 
hydrological zones of Colombia. Even adjusting only for the range of 10 to $100 \%$ of permanence, the errors obtained ranged from 8.16 to $44.05 \%$.

Table 1. Monthly permanence streamflows and daily streamflows of the Timbó River, SC.

\begin{tabular}{|c|c|c|c|}
\hline $\begin{array}{l}\text { Permanence } \\
\qquad(\%)\end{array}$ & $\begin{array}{c}\text { Monthly } \\
\text { streamflow } \\
\left(\mathrm{m}^{3} \cdot \mathrm{s}^{-1}\right)\end{array}$ & $\begin{array}{c}\text { Daily } \\
\text { streamflow } \\
\left(\mathrm{m}^{3} \cdot \mathrm{s}^{-1}\right)\end{array}$ & $\begin{array}{c}\text { Difference } \\
(\%)\end{array}$ \\
\hline 98 & 11,679 & 8,554 & 26.8 \\
\hline 95 & 14,427 & 11,507 & 20.2 \\
\hline 90 & 19,528 & 15,180 & 22.3 \\
\hline 85 & 23,290 & 18,040 & 22.5 \\
\hline 80 & 26,291 & 20,680 & 21.3 \\
\hline 75 & 30,091 & 23,610 & 21.5 \\
\hline 70 & 34,057 & 27,260 & 20.0 \\
\hline 65 & 39,288 & 31,310 & 20.3 \\
\hline 60 & 47,257 & 35,750 & 24.3 \\
\hline 55 & 50,944 & 40,460 & 20.6 \\
\hline 50 & 56,833 & 47,075 & 17.2 \\
\hline 45 & 63,769 & 54,140 & 15.1 \\
\hline 40 & 71,209 & 63,450 & 10.9 \\
\hline 35 & 79,955 & 73,570 & 8.0 \\
\hline 30 & 93,042 & 87,100 & 6.4 \\
\hline 25 & 106,904 & 103,000 & 3.7 \\
\hline 20 & 127,634 & 124,000 & 2.8 \\
\hline 15 & 141,148 & 154,100 & -9.2 \\
\hline 10 & 184,396 & 194,960 & -5.7 \\
\hline 5 & 215,581 & 256,890 & -19.2 \\
\hline 2 & 275,419 & 325,180 & -18.1 \\
\hline
\end{tabular}

Figure 4 shows that the models fit well, and can be used for the estimation of streamflows with a determined permanence. These models can be useful in the hydrological regionalization of streamflows, since the average long-term streamflow is a variable that can be regionalized easily and, therefore, by applying the models, the permanence curve can be obtained for different points of the basin.

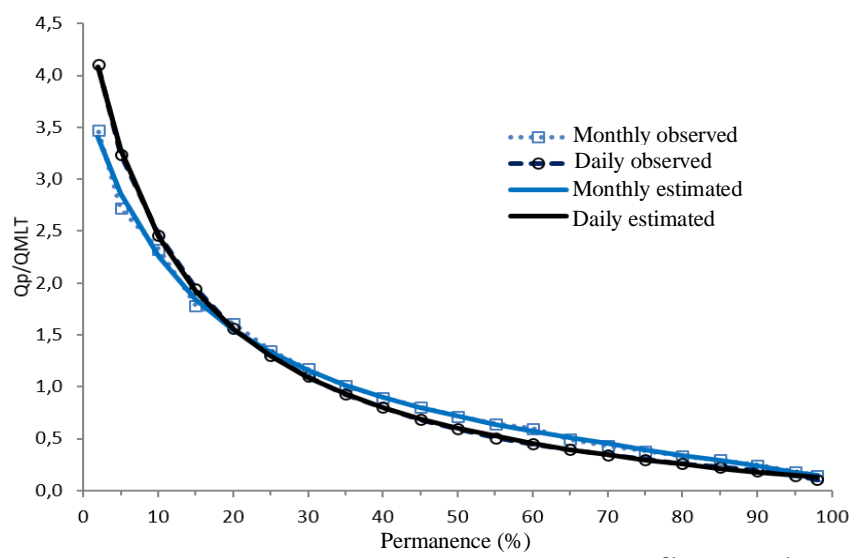

Figure 4. Permanence curve of monthly streamflows and daily streamflow rates dimensioned by the long-term. average streamflow of the Timbó River.

Table 2 shows the values for daily streamflow permanence curve considering the data of each month individually. This analysis may be important in places where there is a marked seasonality in streamflow and/or demand, such as the demand for concentrated irrigation at some time of the year. In these cases, for the granting of water, the seasonality of supply should be considered.

Table 2. Permanence of daily streamflows $\left(\mathrm{m}^{3} \cdot \mathrm{s}^{-1}\right)$ for each month in the Timbó river, SC.

\begin{tabular}{|c|c|c|c|c|c|c|}
\hline $\begin{array}{l}\text { Per. } \\
(\%)\end{array}$ & Jan. & Feb. & Mar. & Apr. & May & June \\
\hline 98 & 10.6 & 10.4 & 11.6 & 8.4 & 7.2 & 9.0 \\
\hline 95 & 14.1 & 13.5 & 13.6 & 10.0 & 8.9 & 10.5 \\
\hline 90 & 17.2 & 17.5 & 16.7 & 12.9 & 11.3 & 13.1 \\
\hline 85 & 19.0 & 20.7 & 19.3 & 15.0 & 13.1 & 15.0 \\
\hline 80 & 21.3 & 25.3 & 22.8 & 16.7 & 14.6 & 16.7 \\
\hline 75 & 24.8 & 30.5 & 26.8 & 18.5 & 16.8 & 18.5 \\
\hline 70 & 28.5 & 34.4 & 31.1 & 20.7 & 18.8 & 22.1 \\
\hline 65 & 32.8 & 38.9 & 35.4 & 22.2 & 20.7 & 25.8 \\
\hline 60 & 37.0 & 43.1 & 40.1 & 23.9 & 23.2 & 30.7 \\
\hline 55 & 41.4 & 47.9 & 44.3 & 25.9 & 26.1 & 37.3 \\
\hline 50 & 48.0 & 54.9 & 49.1 & 27.8 & 30.4 & 45.8 \\
\hline 45 & 52.9 & 64.1 & 54.5 & 30.7 & 36.1 & 57.8 \\
\hline 40 & 60.4 & 71.2 & 63.2 & 34.5 & 45.1 & 68.6 \\
\hline 35 & 71.7 & 80.5 & 71.9 & 39.1 & 55.2 & 80.3 \\
\hline 30 & 85.5 & 94.4 & 81.7 & 45.1 & 67.8 & 98.1 \\
\hline 25 & 101.3 & 115.2 & 98.0 & 55.3 & 86.2 & 114.7 \\
\hline 20 & 119.1 & 146.0 & 120.9 & 65.5 & 115.4 & 141.5 \\
\hline 15 & 140.2 & 163.2 & 147.8 & 77.9 & 155.5 & 175.8 \\
\hline 10 & 178.0 & 184.5 & 174.4 & 96.0 & 209.6 & 227.4 \\
\hline 5 & 239.0 & 214.3 & 212.3 & 174.0 & 285.0 & 282.4 \\
\hline 2 & 352.8 & 261.2 & 260.0 & 284.6 & 353.0 & 428.6 \\
\hline $\begin{array}{l}\text { Per. } \\
(\%)\end{array}$ & July & Aug. & Sept. & Oct. & Nov. & Dec. \\
\hline 98 & 6.9 & 6.8 & 8.9 & 10.2 & 16.1 & 8.1 \\
\hline 95 & 9.6 & 9.6 & 11.4 & 17.0 & 19.5 & 14.8 \\
\hline 90 & 14.4 & 15.0 & 13.3 & 20.7 & 23.0 & 17.1 \\
\hline 85 & 19.1 & 17.8 & 16.8 & 24.3 & 26.2 & 20.5 \\
\hline 80 & 23.0 & 19.8 & 19.0 & 32.1 & 29.6 & 23.9 \\
\hline 75 & 27.9 & 22.1 & 22.2 & 39.1 & 33.5 & 27.5 \\
\hline 70 & 32.1 & 25.0 & 24.7 & 45.8 & 36.7 & 31.0 \\
\hline 65 & 36.1 & 28.7 & 28.7 & 54.1 & 40.4 & 34.8 \\
\hline 60 & 41.5 & 32.2 & 34.2 & 64.5 & 44.3 & 37.1 \\
\hline 55 & 47.3 & 36.5 & 39.4 & 75.4 & 49.1 & 40.7 \\
\hline 50 & 52.9 & 41.1 & 48.8 & 86.7 & 54.4 & 46.4 \\
\hline 45 & 61.2 & 49.4 & 56.0 & 99.8 & 61.7 & 54.4 \\
\hline 40 & 74.1 & 60.3 & 67.8 & 113.0 & 70.3 & 60.9 \\
\hline 35 & 88.0 & 70.5 & 85.4 & 130.3 & 81.6 & 69.1 \\
\hline 30 & 102.0 & 83.6 & 103.0 & 155.6 & 92.3 & 77.6 \\
\hline 25 & 118.6 & 96.3 & 119.2 & 179.8 & 105.4 & 88.6 \\
\hline 20 & 142.5 & 114.3 & 141.7 & 206.6 & 124.0 & 102.3 \\
\hline 15 & 140.2 & 163.2 & 147.8 & 77.9 & 155.5 & 175.8 \\
\hline 10 & 178.0 & 184.5 & 174.4 & 96.0 & 209.6 & 227.4 \\
\hline 5 & 239.0 & 214.3 & 212.3 & 174.0 & 285.0 & 282.4 \\
\hline 2 & 352.8 & 261.2 & 260.0 & 284.6 & 353.0 & 428.6 \\
\hline
\end{tabular}


Based on the annual $\mathrm{Q}_{98}$ of $8.55 \mathrm{~m}^{3} \cdot \mathrm{s}^{-1}$ (Table 1), only the months of April, May, July, August and December do not meet the criteria. If the demand is concentrated in January to March, a value greater than $\mathrm{Q}_{98}$, based on the annual series, could be granted, guaranteeing a greater availability of water for irrigation.

Cruz and Tucci (2008) pointed out the importance for the definition of granting streamflows considering seasonality through the determination of curves of monthly permanence. This strategy improves the information for the manager, allowing the flexibility and rationalization of the releases of water use in function of the different periods of water supply. Pruski et al. (2014) have concluded that the use of the monthly $\mathrm{Q}_{95}$ instead of annual $\mathrm{Q}_{95}$ streamflow implies variations in potential ranging from reductions of up to $37 \%$ in the months of greatest water restriction to values exceeding $100 \%$ in the months of greatest abundance. Therefore, its use allows a more rational and safe use of water resources. Silva, Silva and Moreira (2015) also concluded that the use of criteria based on seasonal water behavior facilitates flexibility in grantable streamflow rates. Bof et al. (2013) recommended the use of monthly and seasonal streamflow-based criteria for a better management of water use in river basins.

Table 3 shows the values of coefficients of the fitted equation for streamflow estimation by the Rational model, as shown in Figures 5 and 6.
Table 3. Coefficients fitted for each month with respective estimation standard error $(\sigma)$ and coefficient of determination $\left(\mathrm{R}^{2}\right)$.

\begin{tabular}{lcccccc}
\hline & \multicolumn{8}{c}{ Coefficients of the Rational model } & & \\
\cline { 2 - 5 } Month & $\mathrm{a}$ & $\mathrm{b}$ & $\mathrm{c}$ & $\mathrm{d}$ & $\sigma$ & $\mathrm{R}^{2}$ \\
\hline Jan. & 5.74463 & -0.05421 & 0.13259 & -0.00110 & 0.0788 & 0.9957 \\
Feb. & 3.42914 & -0.02546 & 0.03468 & 0.00014 & 0.0645 & 0.9958 \\
Mar. & 4.70023 & -0.03444 & 0.05490 & -0.00001 & 0.0555 & 0.9981 \\
Apr. & 9.59832 & -0.09697 & 0.33094 & -0.00343 & 0.0761 & 0.9972 \\
May & 5.50597 & -0.01327 & 0.05794 & 0.00288 & 0.0242 & 0.9997 \\
June & 5.85734 & -0.05513 & 0.11885 & -0.00053 & 0.1098 & 0.9931 \\
July & 4.03815 & -0.03507 & 0.05287 & -0.00004 & 0.0226 & 0.9996 \\
Aug. & 4.47386 & -0.03337 & 0.06460 & 0.00015 & 0.0347 & 0.9991 \\
Sept. & 4.41985 & -0.02879 & 0.04641 & 0.00083 & 0.0274 & 0.9990 \\
Oct. & 3.58807 & -0.03284 & 0.03849 & -0.00007 & 0.0225 & 0.9990 \\
Nov. & 4.28608 & -0.03352 & 0.07812 & -0.00042 & 0.0307 & 0.9991 \\
Dec. & 4.18224 & -0.04009 & 0.07645 & -0.00069 & 0.0335 & 0.9989 \\
\hline
\end{tabular}

The fitted models presented an estimation standard error lower than 0.08 , except for the month of June, when the estimate standard error was 0.1098. However, all coefficients of determination $\left(\mathrm{R}^{2}\right)$ were higher than 0.990 , showing a good fit of the models. These equations facilitate the use of computational models and computer programs in the management of water resources.
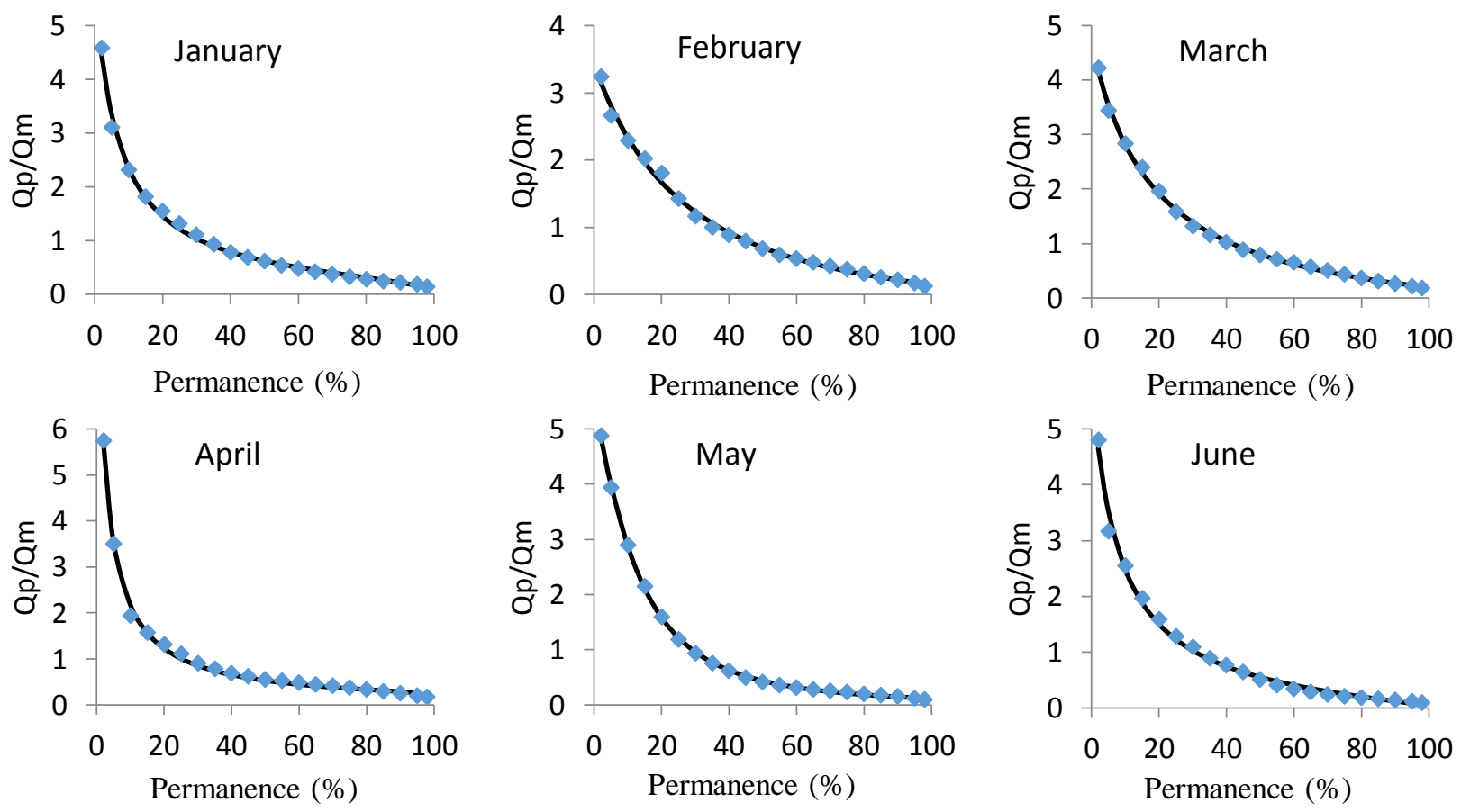

Figure 5. Observed permanence curves (blue dots) and the model (black line) of daily dimensionless streamflows for the months of January to June. 

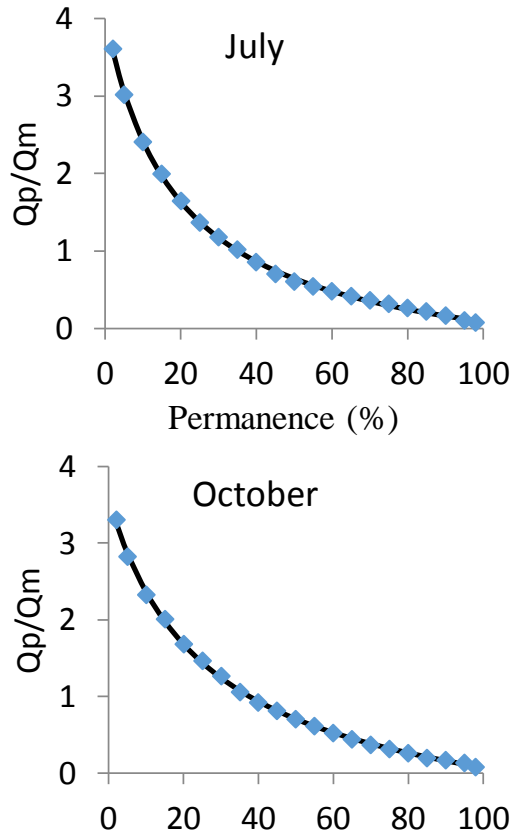

Permanence $(\%)$
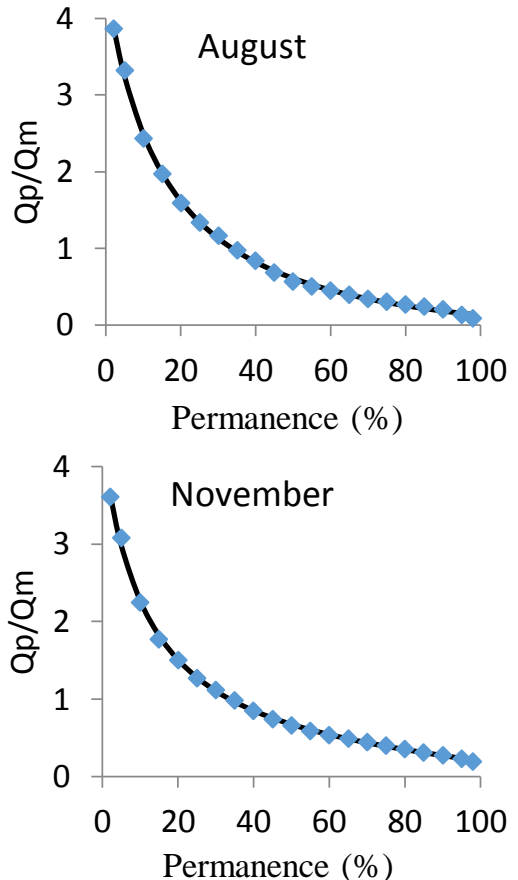
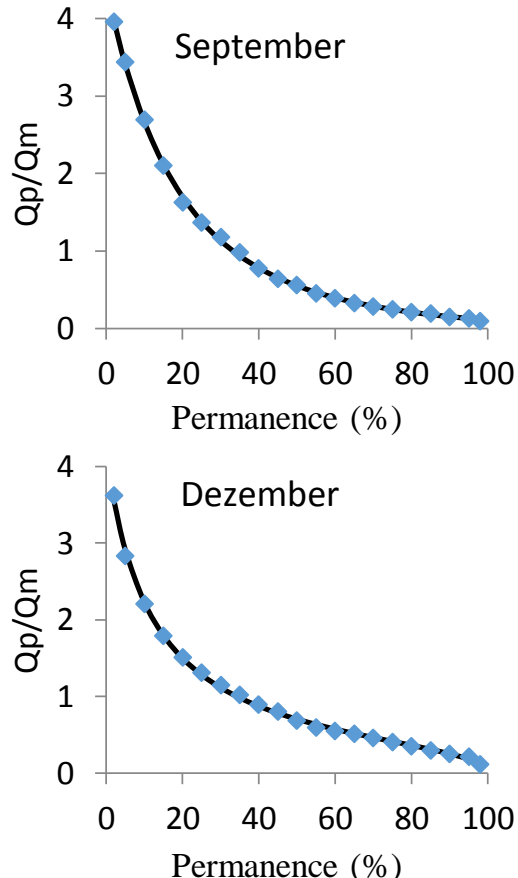

Figure 6. Observed permanence curves (blue dots) and the model (black line) of daily dimensionless streamflows for the months of July to December.

\section{Conclusions}

The use of the monthly permanence curve overestimates the streamflow values for frequencies higher than $20 \%$. Therefore, in hydroelectric projects by run-of-river or in cases of water capturing without reservoirs, one must consider the curve of permanence based on daily streamflow values. Thus, it may be possible to reduce the capacity of the project and interfere with the streamflow taking into account environmental preservation, as recommended by environmental agencies. It is recommended for future works to compare the calculated firm energy using monthly streamflows and daily streamflows, and to verify the impacts that it may cause on the design of the turbines for hydropower generation.

The adjusted models allow estimating the streamflow with a certain permanence level based on the average longterm streamflow or based on the average monthly streamflow values.

The determination of the monthly permanence curve allows the flexibility of water granting criteria, considering the seasonality of supply and demand of water resources and improving the management of water resources.

\section{References}

Arias, S.G., \& Serna, L.F.C. (2017). Regionalización de curvas de duración de caudales em el departamento de Atioquia-Colombia. Revista EIA, 14(27), 21-30. doi: doi.org/10.24050/reia.v14i27.1158

Bof, L.H.N., Pruski, F.F., Silva, L.M.C., \& Justino, F. (2013). Analysis of Appropriate Timescales for Water Diversion Permits in Brazil. Environmental Management, 51(2), 492-500. doi: 10.1007/s00267-0129982-7

Calmon, P.A.S., Souza, J.C., Reis, J.A.T., \& Mendonça, A.S.F. (2016). Uso combinado de curvas de permanência de qualidade e modelagem da autodepuração como ferramenta para suporte ao processo de enquadramento de cursos d'água superficiais. Revista Brasileira de Recursos Hídricos, 21(1), 118-133. doi: 10.21168/rbrh.v21n1.p108-133

Cruz, J.C., \& Tucci, C.E.M. (2008). Estimativa da disponibilidade hídrica através da curva de permanência. Revista Brasileira de recursos hídricos, 13(1), 111-124. doi: 10.21168/rbrh.v13n1.p111-124

Cunha, D.G.F., Calijuri, M.C., \& Mendiondo, E.M. (2012). Integração ente curvas de permanência de quantidade e qualidade a água como uma ferramenta para gestão eficiente dos recursos hídricos. Engenharia Sanitária e Ambiental, 17(4), 369-376. doi: doi.org/10.1590/S141341522012000400003

Eletrobras. (2000). Diretrizes para estudos e projetos de Pequenas Centrais Hidrelétricas. Centrais Hidrelétricas Brasileiras S.A. - Eletrobrás.

Eslamian, S., \& Biabanaki, M. (2008). Low flow regionalization modeling. International Journal of Ecological Economics \& Statistics, 12(8), 82-97.

Cerqueira Ferreira, D.M., Fernandes, V.S., \& Kaviski, E. (2016). Curvas de permanência de qualidade da água como subsídio para o enquadramento de corpos d'água a partir de modelagem matemática em regime não permanente. Revista Brasileira de Recursos Hídricos, 21(3), 479-492. doi: doi.org/10.1590/2318-0331.011615143

Fioreze, A.P., \& Oliveira, L.F.C. (2010). Usos dos recursos hídricos da Bacia Hidrográfica do Ribeirão Santa Bárbara, Goiás, Brasil. Pesquisa Agropecuária Tropical, 40(1), 28-35. doi: 10.5216/pat.v40i1.3869

Gasques, A.C.F., Neves, G.L., Santos, J.D., Mauad, F.F., \& Okawa, C.M.P. (2018). Regionalização de vazões mínimas: Breve revisão Teórica. Revista Eletrônica de Engenharia Civil, 14(2), 60-70. doi: https://doi.org/10.5216/reec.v14i2.47105

Mello, C.R., Viola, M.R., \& Beskow, S. (2011). Vazões máximas e mínimas para bacias hidrográficas da região Alto Rio Grande, MG. Ciência e Agrotecnologia, 34(2), 494-502. doi: doi.org/10.1590/S141370542010000200031

Oliveira L.F.C., \& Fioreze A.P. (2011). Estimativas de vazões mínimas mediante dados pluviométricos na Bacia Hidrográfica do Ribeirão Santa Bárbara. Revista Brasileira de Engenharia Agrícola e Ambiental, 15(1), 9-15. doi: doi.org/10.1590/S1415-43662011000100002

Pandey, G.R., \& Nguyen, V.T.V. (1999). A comparative study of regression based methods in regional frequency analysis. Journal of Hydrology, 225(1), 92-101. doi: doi.org/10.1016/S0022-1694(99)00135-3

Pessoa, R.C.L., Blanco, C.J.C., \& Martins, J.R. (2011). Regionalização de curvas de permanência de vazões da região da Calha Norte no Estado do 
Pará. Revista Brasileira de Recursos Hídricos, 16(2), 65-74. doi: 10.21168/rbrh.v16n2.p65-7483

Pereira, G.S., \& Caldeira, F.V. (2018). Avaliação da distribuição de Gumbel na determinação de vazões mínimas das sub-bacia do Rio Negro. Revista Águas Subterrâneas, 32(1), 11-26. doi: dx.doi.org/10.14295/ras.v32i1.28926

Pruski, F.F., Bof, L.H.N, Silva, L.M.C., Silva, J.M.A, Rego, F.S., \& Justino, F.B. (2004). Impact of the substitution of reference annual streamflow by monthly streamflow on the potential use of water resource. Engenharia Agrícola, 34(3), 496-509. doi: doi.org/10.1590/S010069162014000300013

Silva, B.M.B., Silva, D.D., \& Moreira, M.C. (2015). Influência da sazonalidade das vazões nos critérios de outorga de uso da água: estudo de caso da bacia do rio Paraopeba. Revista Ambiente e Agua, 10(3), 623634. doi: doi.org/10.4136/ambi-agua.15875787

Santa Catarina. Secretaria de Estado do Desenvolvimento Sustentável (SDS). (2007). Panorama dos Recursos Hídricos de Santa Catarina. Florianópolis, SC, março de 2007.

Santa Catarina. Secretaria de Estado do Desenvolvimento Sustentável (SDS). 2018. Recursos Hídricos de Santa Catarina. 2018. 31p. Recuperado de http://www.aguas.sc.gov.br/jsmallfib_top/DHRI/bacias_hidrograficas/b acias_hidrograficas_sc.pdf6

Tucci, C.E.M. (2013). Hidrologia: ciência e aplicação. 4. ed. Porto Alegre: Editora da UFRGS/ABRH.

Tucci, C.E.M. (2002). Regionalização de Vazões. Porto Alegre: Universidade Federal do Rio Grande do Sul.

Vestena, L.R., Oliveira, E.D., Cunha, M.C., \& Thomaz, E.L. (2012). Vazão ecológica e disponibilidade hídrica na bacia das Pedras, Guarapuava-PR. Ambi-Agua, 7(3), 212-227. doi: 10.4136/1980-993X

Vasco, A.N., Netto, A.O.A., \& Pruski, F.F. (2017). Impactos das barragens na disponibilidade hídrica do Nordeste do Brasil. Revista Recursos Hídricos, 38(2), 39-49.doi: 10.5894/rh38n2-cti1

License: Creative Commons CC BY 4.0

This article was published with open access for distribution under the terms of the Creative Commons Attribution License, which allows unrestricted use, distribution, and reproduction in any medium, provided the original work is properly cited. 